\title{
Studi Retrospektif Kanker Kulit di Poliklinik Ilmu Kesehatan Kulit dan Kelamin RS Dr. M. Djamil Padang Periode Tahun 2015-2017
}

\author{
Silvia Wilvestra, Sri Lestari, Ennesta Asri
}

\begin{abstract}
Abstrak
Di Indonesia, kanker kulit menempati urutan ketiga setelah kanker leher rahim dan kanker payudara. Faktor peningkatan radiasi sinar ultraviolet, faktor genetik, pola hidup yang tidak sehat, dan infeksi human papillomavirus dapat menjadi pencetus untuk timbulnya kanker kulit. Tujuan: Mengetahui profil kanker kulit di Poliklinik IImu Kesehatan Kulit dan Kelamin RS Dr. M. Djamil Padang dari Januari 2015 - Desember 2017. Metode: Penelitian retrospektif dengan desain deskriptif dari data rekam medis pasien baru. Hasil: Selama periode Januari 2015 Desember 2017, terdapat 38 kasus kanker kulit dari 1.003 kunjungan ke Divisi Tumor dan Bedah Kulit Poli IK. Kulit dan Kelamin RS Dr. M. Djamil Padang. Penelitian ini menemukan kanker kulit pada laki-laki 20 kasus (53\%) dan perempuan 18 kasus (47\%). Karsinoma sel basal 31 kasus (81\%), karsinoma sel skuamosa 6 kasus (16\%), karsinoma sel basoskuamosa 1 kasus $(3 \%)$ dan tidak terdapat kasus melanoma maligna. Usia pasien kanker kulit terbanyak adalah usia 45-64 tahun (58\%). Kesimpulan: Karsinoma non-melanoma merupakan kanker kulit yang paling banyak ditemukan di dunia. Pada penelitian ini kanker kulit yang paling banyak ditemukan adalah karsinoma sel basal dengan pasien laki-laki lebih banyak daripada perempuan, dan kelompok usia terbanyak adalah 45-64 tahun.
\end{abstract}

Kata kunci: studi retrospektif, kanker kulit

\begin{abstract}
Background: Skin cancer places on number three after cervical cancer and breast cancer in Indonesia. Increased of ultraviolet radiation, genetic factors, unhealthy lifestyles, and infection of human papillomavirus can trigger skin cancer. Aim: Knowing the profile of skin cancer at the Dermatology and Venereology Outpatient Dr. M. Djamil Hospital Padang from January 2015 - December 2017. Methods: This study was conducted retrospectively based on medical record data. Results: During the period January 2015 - December 2017, there were 38 skin cancer cases from 1,003 visits to the Tumor and Skin Surgery Division of Dermatology and Venereology Outpatient Dr. M. Djamil Hospital Padang. Patients were 20 male (53\%) and 18 female (47\%). Basal cell carcinoma 31 cases (81\%), squamous cell carcinoma 6 cases (16\%), basosquamous cell carcinoma 1 case (3\%) and no cases of malignant melanoma. It occurred more frequently in age group of 45-64 years with 22 cases (58\%). Conclusion: Nonmelanoma skin cencer is the most common skin cancer worldwide. In this study the most common skin cancer is basal cell carcinoma, male patients are more commonly found and it occurred more frequently in age group of 45-64 years.
\end{abstract}

Keywords:Retrospective study, skin cancer

Affiliasi penulis: Bagian IImu Kesehatan Kulit dan Kelamin RS Dr. M. Djamil / Fakultas Kedokteran Universitas Andalas, Padang Korespondensi: silvia.ikrar@gmail.com

Telp: 0751-810256

\section{PENDAHULUAN}

Kanker kulit adalah benjolan atau pertumbuhan yang berlebihan jaringan kulit yang mengenai sebagian atau seluruh lapisan kulit, yang memiliki struktur tidak teratur dengan diferensiasi sel dalam berbagai tingkatan pada kromatin, nukleus dan sitoplasma, bersifat ekspansif, infiltratif hingga merusak jaringan sekitarnya, serta bermetastasis melalui pembuluh darah dan atau pembuluh getah bening. Kanker kulit dapat diklasifikasikan dalam tiga tipe terbanyak yaitu karsinoma sel basal, karsinoma sel skuamosa, dan melanoma maligna. ${ }^{1}$

Kanker kulit merupakan salah satu kanker yang paling umum didiagnosis di seluruh dunia, terutama pada populasi berkulit putih, insiden dan kematian terus meningkat selama dekade terakhir. Insiden kanker kulit di Amerika tercatat 4,9 juta kasus pada tahun 2007-2011.2 Di Indonesia, kanker kulit menempati urutan ketiga setelah kanker rahim dan kanker payudara. ${ }^{3}$ Kanker kulit dijumpai 5,9-7,8\% dari semua jenis kanker pertahun. Kanker kulit yang paling banyak di Indonesia adalah karsinoma sel basal $(65,5 \%)$, diikuti karsinoma sel skuamosa (23\%), melanoma maligna $(7,9 \%)$ dan kanker kulit lainnya. ${ }^{4}$ Bentuk yang paling invasif kanker kulit adalah melanoma, memiliki tingkat kematian yang tinggi, terutama jika tidak terdeteksi dini. Kanker kulit nonmelanoma (NMS Cs), seperti karsinoma sel basal dan karsinoma sel skuamosa lebih umum tetapi metastasisnya kurang, dan hanya sebagian kecil yang mengarah kekematian. ${ }^{2}$

Tujuan penelitian untuk mengetahui insiden kanker kulit, distribusi menurut jenis kelamin dan kelompokan umur di Poliklinik IImu Kesehatan Kulit dan Kelamin RS Dr. M. Djamil Padang selama periode Januari 2015 - Desember 2017. 


\section{METODE}

Subjek penelitian diambil dari catatan medik pasien baru kanker kulit di Poliklinik IImu Kesehatan Kulit dan Kelamin RS Dr. M. Djamil Padang selama periode Januari 2015 - Desember 2017. Metode penelitian ini secara retrospektif dimana hasil pencatatan dari subjek penelitian dikelompokkan berdasarkan jenis kanker kulit, distribusi jenis kelamin dan usia.

\section{HASIL}

Tabel 1. Jumlah kunjungan pasien baru dengan tumor kulit di Divisi Tumor dan Bedah Kulit di Poliklinik IK. Kulit dan Kelamin RS Dr. M. Djamil Padang periode Januari 2015 - Desember 2017

\begin{tabular}{lllll}
\hline $\begin{array}{l}\text { Jumlah } \\
\text { kunjungan } \\
\text { baru }\end{array}$ & 2015 & 2016 & 2017 & Jumlah \\
\cline { 2 - 4 } & 334 & 346 & 323 & 1.003 \\
\hline $\begin{array}{l}\text { Total pasien } \\
\text { Pasien tumor }\end{array}$ & 107 & 115 & 98 & 320 \\
$\begin{array}{l}\text { jinak } \\
\begin{array}{l}\text { Pasien kanker } \\
\text { kulit } \\
\% \text { pasien baru }\end{array}\end{array}$ & 12 & 17 & 9 & 38 \\
kanker kulit & $3,5 \%$ & $4,9 \%$ & $2,7 \%$ & $3,7 \%$ \\
\hline
\end{tabular}

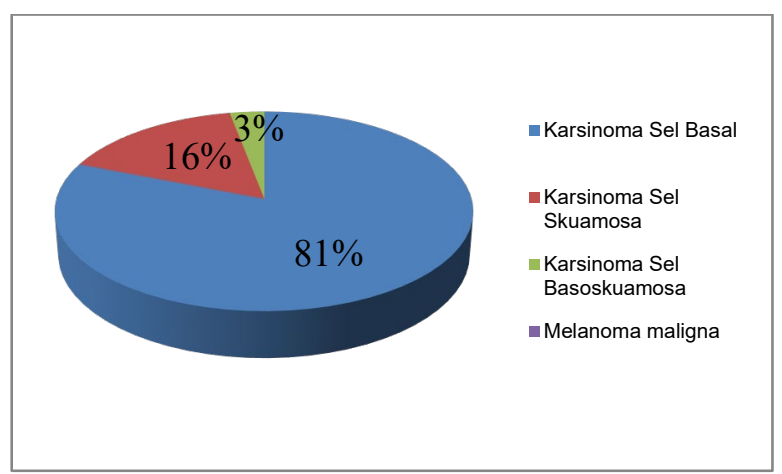

Gambar 1. Sebaran kanker kulit di Poliklinik IK. Kulit dan Kelamin RS Dr. M. Djamil Padang periode Januari 2015 - Desember 2017

Tabel 2. Sebaran kanker kulit di Poliklinik IK. Kulit dan Kelamin RSUP Dr. M. Djamil Padang berdasarkan jenis kelamin periode Januari 2015 - Desember 2017

\begin{tabular}{|c|c|c|c|}
\hline \multirow[t]{2}{*}{ Diagnosis } & \multicolumn{2}{|c|}{ Jenis Kelamin } & \multirow{2}{*}{$\begin{array}{l}\text { Jumlah } \\
(\%)\end{array}$} \\
\hline & Laki-laki & Perempuan & \\
\hline $\begin{array}{l}\text { Karsinoma Sel } \\
\text { Basal }\end{array}$ & 15 & 16 & $31(81)$ \\
\hline $\begin{array}{l}\text { Karsinoma Sel } \\
\text { Skuamosa }\end{array}$ & 4 & 2 & $6(16)$ \\
\hline $\begin{array}{l}\text { Karsinoma Sel } \\
\text { Basoskuamosa }\end{array}$ & 1 & 0 & $1(3)$ \\
\hline $\begin{array}{l}\text { Melanoma } \\
\text { Maligna }\end{array}$ & 0 & 0 & 0 \\
\hline Jumlah (\%) & $20(53)$ & $18(47)$ & $38(100)$ \\
\hline
\end{tabular}

Berdasarkan pencatatan kunjungan pasien di Divisi Tumor dan Bedah Kulit Poliklinik Ilmu Kesehatan Kulit dan Kelamin RS Dr. M. Djamil Padang selama periode Januari 2015 - Desember 2017 ditemukan kanker kulit sebanyak 38 kasus $(3,7 \%)$, dimana kanker kulit pada laki-laki 20 kasus (53\%) dan perempuan 18 kasus (47\%). Karsinoma sel basal 31 kasus (81\%), karsinoma sel skuamosa 6 kasus (16\%), karsinoma sel basoskuamosa 1 kasus (3\%) dan tidak terdapat kasus melanoma maligna. Usia pasien kanker kulit terbanyak pada usia 45 - 64 tahun yaitu 22 kasus (58\%).

Gambar 2. Sebaran kanker kulit di Poliklinik IK. Kulit dan Kelamin RSUP Dr. M. Djamil Padang berdasarkan usia periode Januari 2015 - Desember 2017

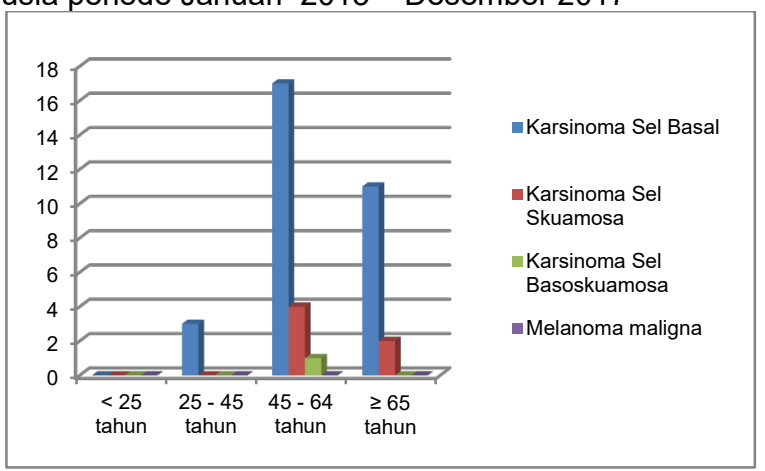

\section{PEMBAHASAN}

Jumlah kasus baru kanker kulit terhadap seluruh jumlah kunjungan pasien ke Divis Tumor dan Bedah Kulit Poliklinik Kulit dan Kelamin RS Dr. M. Djamil selama periode Januari 2015 - Desember 2017 adalah 38 kasus dari 1.003 kunjungan. Pada penelitian retrospektif ini menunjukkan insiden terbanyak adalah karsinoma sel basal (81\%) kemudian diikuti dengan karsinoma sel skuamosa (16\%). Kanker kulit ditegakkan dari anamnesis, pemeriksaan fisik dan pemeriksaan histopatologi. ${ }^{1}$

Insiden kanker kulit di Amerika tercatat 4,9 juta kasus pada tahun 2007 - 2011 dengan rasio kanker non melanoma (kanker sel basal dan kanker sel skuamosa) dengan melanoma maligna adalah $6: 1 .^{2} \mathrm{Di}$ Jerman pada tahun 2014 diperkirakan 20.000 kasus baru melanoma maligna, 150.000 kasus karsinoma sel basal dan 37.000 kasus karsinoma sel skuamosa. ${ }^{5} \mathrm{Di}$ Indonesia kanker kulit menempat urutan ketiga setelah kanker leher rahim dan kanker payudara. ${ }^{6}$ Kasus kanker kulit yang paling banyak di Indonesia adalah kanker sel basal $(65,5 \%)$, diikuti karsinoma sel skuamosa $(23,3 \%)$ dan melanoma maligna $(7,9 \%)$ dan tumor lainnya $(3,6 \%) .{ }^{4}$ Pada penelitian ini kanker kulit terbanyak juga kanker sel basal $(81 \%)$, diikuti karsinoma sel skuamosa (16\%) (Diagram 1).

Penelitian Sibarani dkk. di RSUP H. Adam malik Medan selama 3 tahun $(2005$ - 2007) mendapatkan pasien kanker kulit sebanyak $5,74 \%$ dari 296 kasus tumor kulit, terdiri dari 106 pasien laki-laki (35,6\%) dan 190 pasien perempuan $(64,4 \%)$ dengan rasio $1: 1,79 .{ }^{7}$ Penelitian Gunawan dkk. di RSUP Prof. Dr. R.D. Kandou Manado selama 3 tahun mendapatkan pasien kanker kulit 50 orang $(8,5 \%)$ dari 588 kasus tumor kulit, terdiri dari 22 orang laki-laki (44\%) dan 28 orang perempuan (56\%). ${ }^{8}$ Pada penelitian ini, terdapat 38 kasus $(3,7 \%)$ dari 1.003 kunjungan (Tabel 1), dimana kanker kulit pada laki-laki 20 kasus (53\%) dan perempuan 18 kasus (47\%) (Tabel 2).

Kanker kulit dapat mengenai usia 45 tahun dan paling banyak ditemukan pada geriatri. Faktor predisposisinya adalah faktor lingkungan (pajanan sinar matahari kronis, bahan kimia, trauma, dsb) dan genetik. Eiseman dkk. (Jerman, 2014) melaporkan kasus kanker kulit di Schleswig-Holstein pada periode 
Juli 2008 - Desember 2010 paling banyak pada usia 60-79 tahun. ${ }^{9}$ Penelitian yang dilakukan oleh Gunawan dkk. di RSUP Manado periode 2008 - 2010 diperoleh $52 \%$ kasus di usia $>64$ tahun dan $26 \%$ pada usia $45-$ 64 tahun. $^{8}$ Namun pada penelitian ini didapatkan kanker kulit terbanyak pada usia 45-64 tahun yaitu 22 kasus $(58 \%)$ diikuti usia $\geq 65$ tahun sebanyak 13 kasus (34\%) (Diagram 2).

Kanker kulit di Indonesia kurang mendapatkan perhatian karena jarang menyebabkan kematian dan gangguan berarti, sehingga cenderung diabaikan. Dengan peningkatan pajanan radiasi ultraviolet, insiden kanker kulit tampaknya akan semakin meningkat. Risiko ini dapat dikurangi dengan penggunaan pelinding sinar matahari misalnya tabir surya SPF > 33 dan pakaian yang tepat. ${ }^{1,8}$

\section{SIMPULAN}

Pada penelitian ini, karsinoma sel basal merupakan kanker kulit terbanyak ditemukan, sama hal nya dengan penelitian yang lain. Pasien laki-laki lebih banyak dibandingkan pasien perempuan dan usia terbanyak adalah 45-64 tahun.

\section{DAFTAR PUSTAKA}

1. Kawasumi $M$, Nghiem $P$. Ultraviolet radiation carcinogenesis. Dalam: Wolff K, Goldsmith LA, Katz SI, Gilchrest BA, Paller AS, Leffel DJ, editor. Fitzpatrick's dermatology in general medicine. Edisi ke-8. New York: McGraw Hill Companies; 2012. h.1251-1260.

2. Guy GP, Machlin SR, Ekwueme DU, Yabroff KR. Prevalence and costs of skin cancer treatment in the U.S., 2002-2006 and 2007-2011. American Journal Prevention Medicine. 2014: 1-5.

3. Badan Penelitian dan Pengembangan Kementerian Kesehatan RI. RISKESDAS 2007. Jakarta: Kementerian Kesehatan RI; 2007.

4. Cipto H, Suriadiredja AS. Tumor kulit. Dalam: Menaldi SL, Bramono K, Indriatmi W, editor. IImu penyakit kulit dan kelamin. Edisi ketujuh. Jakarta: Badan Penerbit FKUI; 2016. h.262-276.

5. Katalinic A, Elsemann N, Waldman A. Skin cancer screening in Germany. Deutsches Arzteblatt International. 2015; 112: 629-634.

6. Dewi M. Sebaran kanker di Indonesia, riset kesehatan dasar 2007. Indonesian Journal of Cancer. 2017; 11(29):1-8.

7. Sibarani MNO, Dalimunthe DA, Putra IB. Tumor kulit di Poliklinik Kulit dan Kelamin RSUP $\mathrm{H}$. Adam Malik Medan. Disampaikan pada Kongres Nasional PERDOSKI XII. Palembang 2 - 5 Juli 2011.

8. Gunawan D, Wijaya LV, Oroh EE. Tumor kulit ganas di Poliklinik Kulit dan Kelamin RSUP Prof Dr RD Kandou Manado. Media DermatoVenereologica Indonesiana. 2011; 38(2):63-69.

9. Eisemann N, Waldmann A, Geller AC, Weinstock MA, Volkmer B, Geinert R, dkk. Non-melanoma skin cancer incidence and impact of skin cancer screening on incidence. The Society for Investigative Dermatology. 2014; 134:43-50. 